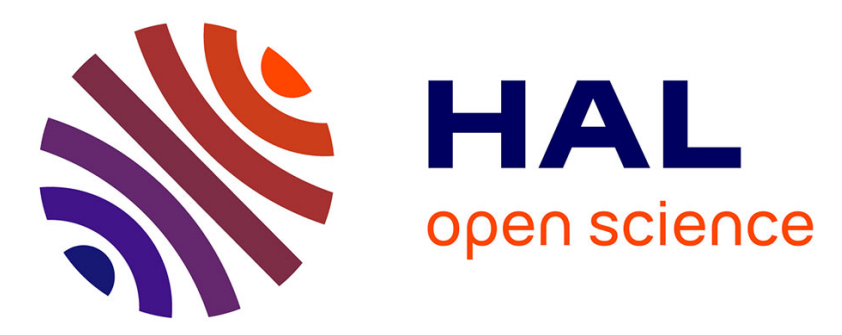

\title{
The Puerto affair: revealing the difficulties of the fight against doping
}

Bastien Soulé, Ludovic Lestrelin

\section{To cite this version:}

Bastien Soulé, Ludovic Lestrelin. The Puerto affair: revealing the difficulties of the fight against doping. Journal of Sport and Social Issues, 2011, 35 (2), pp.186-208. 10.1177/0193723511405478 . hal-02087123

HAL Id: hal-02087123

https://hal-normandie-univ.archives-ouvertes.fr/hal-02087123

Submitted on 1 Apr 2019

HAL is a multi-disciplinary open access archive for the deposit and dissemination of scientific research documents, whether they are published or not. The documents may come from teaching and research institutions in France or abroad, or from public or private research centers.
L'archive ouverte pluridisciplinaire HAL, est destinée au dépôt et à la diffusion de documents scientifiques de niveau recherche, publiés ou non, émanant des établissements d'enseignement et de recherche français ou étrangers, des laboratoires publics ou privés. 


\title{
The Puerto affair: revealing the difficulties of the fight against doping
}

\author{
Bastien Soulé \& Ludovic Lestrelin
}

Soulé B., Lestrelin L., 2011, « The Puerto Affair: revealing the difficulties of the fight against doping », Journal of Sport \& Social Issues, vol. 35, n², p. 186-208.

In 1998, the infamous Festina affair revealed how routinely erythropoietin (commonly known as EPO) was used by professional cycling teams. Eight years later, another scandal linked to doping by cyclists made the headlines after an investigation by the anti-doping section of the Spanish Guardia Civil (under the name "Operation Puerto") led to the identification of a network which was taking blood samples of cyclists. Processed in a way that produced an artificial concentration of red blood cells, the blood was frozen and then re-injected in the cyclists at key moments of the season in order to improve their performance by increasing the oxygen supply to the muscles ${ }^{1}$. Since 2004 the World Anti-Doping Agency (WADA) has banned blood transfusions during or outside competitions (De Mondenard, 2006). Why is this more recent affair ${ }^{2}$ interesting for scientists now that it is such a well known fact that cycling and doping go hand in hand (Rabenstein, 1997; Hoberman, 1992)? Beyond the size of the

\footnotetext{
${ }^{1}$ Le Monde, 1 June 2006 ; Libération, 16 February 2008.

${ }^{2}$ As explained by Duret and Trabal (2001) scandals are types of shared indignation which generally reinforces the position of the federal institution through a mostly internal treatment; affairs, on the contrary, are characterized by the intervention of society as a whole (authorities, judges, experts, media as well as public opinion). This analysis will demonstrate that talking of a simple scandal would be inappropriate; on the other hand, referring to the affair as "Operation Puerto" would be reductive, this term referring only to the police action which led to the original identification of the network. This is why, in this article, we will use the term "Puerto affair".
} 
network, which in itself was impressive $\mathrm{e}^{3}$, and the relative novelty of the process that was used, this case reveals the difficulties of the fight against doping of professional cyclists. These difficulties, analyzed using a systemic approach, will constitute the core theme of this article, of which the Puerto affair is just one example.

\section{The chronology of the affair and its protagonists}

Following his exclusion from the Kelme team in 2004, Spanish cyclist Manzano divulged the doping practices used by this Spanish team in great detail ${ }^{4}$. These disclosures started a long police investigation which led to, among other things, the discovery of an underground laboratory located in a Madrid apartment belonging to Dr Fuentes. This is where the blood samples were taken and stored. Other ergogenic ${ }^{5}$ materials were found there as well and seized by the Guardia Civil: anabolic steroids, growth hormones, testosterone, thousands of doses of EPO, many drugs, about a hundred bags of frozen blood and as many bags of plasma. Next to these bags were documents revealing a doping system based on blood transfusions, administered to many athletes whose identities could not be immediately ascertained due to the use of both numbers and codenames ${ }^{6}$. Medical equipment necessary for sampling, processing, and preserving the blood was also found. And lastly, four months of

\footnotetext{
${ }^{3}$ The number of professional athletes which were clients of the network is estimated at about 200 (Le Figaro, 27 April 2007).

${ }^{4}$ Growth hormones and EPO, blood transfusions, as well as masking of illicit products before and during checks (claims published by the Spanish sports daily $A s$, in five consecutive articles, between the $24^{\text {th }}$ and the $29^{\text {th }}$ of March 2004).

${ }^{5}$ That is, optimizing human performance (De Leseleuc \& Marcellini, 2005).

${ }^{6}$ L'Equipe, 1 July 2006 ; Le Monde, 1 June 2006.
} 
phone conversations and videos of the comings and goings at this "laboratory" as well as at two other similar sites in Madrid and Saragossa, were recorded.

Five people were arrested on 23 May 2006. Besides Dr Fuentes (former doctor of several Spanish teams: Kelme, Once, etc.), also arrested were: Saiz (then sports manager of the Spanish team Liberty Seguros), Labarta (associate sports manager of the team Communidad Valenciana), Dr Merinos (hematologist and director of a medical laboratory) and, finally, Leon (former mountain biker and Dr Fuentes' helper). The two doctors were the only ones taken into temporary custody, only to be freed after posting a 120,000 euro bail each.

Based on the judicial report, to which it had early and unauthorized access ${ }^{7}$, the newspaper $E l$ Pais of 25 June 2006, reveals that 58 professional cyclists, among whom some top racers (Ullrich, Basso, Mancebo, Beloki, Contador and Sevilla) used Dr Fuentes' "treatments." Several sponsors of teams which had "Puertists" among them (the name given to the cyclists suspected of being implicated in the affair) reacted by withdrawing their financial support ${ }^{8}$. Some cyclists and teams were rejected from participating in major events ${ }^{9}$. Following this affair, five professional teams were dissolved and a number of cyclists were forced into early

\footnotetext{
${ }^{7}$ Probable consequence of this "leak": on 30 June 2006, the Guardia Civil officially transmitted the file to the Spanish Consejo Superior de Deportes (CSD) as well as to Amaury Sport Organisation (organizer and owner of the Tour de France, the beginning of which for 2006 was imminent) and to the Union Cycliste Internationale. ${ }^{8}$ Liberty, an American insurance company, justifies this decision saying: “the implications of Manolo Saiz's detention are highly alarming. They damage our name and cycling’s name” (AFP dispatch, 27 May 2006). No fewer than fifteen "Puertists" were on this team.

${ }^{9}$ This was the case for the team Comunidad Valenciana (of which Labarta was a member) and for the cyclists Ullrich and Basso for the 2006 Tour de France (Libération, 16 February 2008).
} 
retirement (some were fired, and in other cases contracts were not renewed or teams disappeared, etc. $)^{10}$.

On 12 March 2007, Judge Serrano closed the case, arguing that at the time of the affair there was no law in Spain punishing doping (a law was subsequently voted, on 2 November 2006) and that the danger of the products and the methods used had not been proven ${ }^{11}$, which rendered impossible accusations of "public health hazard" or "endangering the lives of others." The magistrate mentioned that none of the twelve cyclists who gave testimony during the procedure had declared receiving blood transfusions. The "Puertists" and the five people arrested on 23 May 2006 were thus cleared of charges.

On 14 March 2007, the Madrid prosecutor's office, representing the Spanish Consejo Superior de Deportes ${ }^{12}$ (CSD), along with the World Anti-Doping Agency (WADA), the Union Cycliste Internationale (UCI) and the Real Federacion Espagnola de Ciclismo (RFEC) appealed this decision, contesting the innocuousness of the methods used by Dr Fuentes. On 14 February 2008, the Madrid court agreed to resume the procedure, with the goal of determining whether Dr Fuentes and his accomplices were abiding by the health rules

\footnotetext{
${ }^{10}$ A year after the "operation" 30 "Puertists" had found refuge in Elite 2 (lower division).

${ }^{11}$ In a report written by experts and dated 22 December 2006, the Madrid National Institute of Toxicology estimated that the level of EPO found in several bags of blood posed no health risk (El Mundo, 18 February 2007). Furthermore, Judge Serrano emphasized the scientific uncertainties concerning the side effects of EPO use. Lastly he minimized the risks associated with blood transfusions, particularly with respect to dangers involved in other doping methods (As, 11 March 2007).

${ }^{12}$ Spanish Ministry of Sports, the government administration in charge of Sports in Spain.
} 
concerning the sampling, storing, preservation and transport of blood ${ }^{13}$. Not considered a legal matter, doping itself is no longer at the core of the debate. In the meantime, the Guardia Civil issued at the end of April 2007 a second Puerto file, of some 6,000 pages in length compared to the 500 pages of the original version. This list of the "Puertists" is longer, increasing from 58 to 107 names, and the evidence permitting the identification of the blood contained in the bags seized the previous year has significantly increased ${ }^{14}$.

The discontent caused by the closing of the case was mixed with growing resentment towards the judiciary system and even towards the Spanish authorities which were more and more openly blamed for not attempting to expose formerly undisclosed practices. The distrust was so profound that the Italian National Olympic Committee (INOC) decided to start an alternative procedure, announcing in January 2008 its intention to hear the people implicated ${ }^{15}$ and indicating the possibility of sanctions ${ }^{16}$.

On 29 September 2008, Judge Serrano again dismissed the case, arguing the absence of new evidence that could lead to prosecution. The prosecutor's office and the CSD immediately filed an appeal ${ }^{17}$ and, on 12 January 2009 , after reviewing the different demands presented, the Madrid provincial court decided that there were indeed elements pointing to a public

\footnotetext{
${ }^{13}$ El Pais, 15 February 2008. The technique of autotransfusion carries some risk, particularly when the sampling is performed in a non-sterile environment or when the blood is not properly preserved.

${ }^{14}$ La Gazzetta dello Sport, 30 March 2007.

${ }^{15}$ L'Equipe and Le Figaro, 10 January 2008. Facing the fact that it was impossible to rely on the Spanish judiciary system, the INOC will give up (AFP, 26 June 2008).

${ }^{16}$ Starting in August 2007, the new Italian anti-doping regulation allows exclusion from participation in competitions of foreign athletes whose doping has been proven.

${ }^{17}$ Libération, 19 November 2008.; L'Equipe, 2 October 2008; As, 4 October 2008.
} 
health violation. The reopening of the case was subsequently requested naming the five people arrested on 23 May 2006 as well as the three presumed accomplices (Belda, former manager of the team Communidad Valenciana; Cordova, former doctor of the team Liberty Seguros; Dr Fuentes' sister, doctor of the team Communidad Valenciana) who could all receive up to two years in prison as well as the revocation of their professional license ${ }^{18}$.

This succession of judiciary decisions, a sign of the conflicting positions of many of the protagonists and of the many ways of looking for proof, attests to the challenge of regulating doping and to the seemingly erratic nature of the regulation. The following analysis aims at supporting and clarifying this observation, in order to bring to light, using this case, the various difficulties of the fight against doping, considering the prevention of ergogenic methods, the sanctions and the ways to end the crisis. We will thus discuss the factors which made it impossible to impede the spreading of doping via auto-transfusion as well as the various attempts at restoring a certain balance - apparent or real - among the professional cyclist elite.

\section{Prevention and regulation of doping: a systemic analysis approach}

Resorting to the use of drugs or methods designed to enhance performance, or rejecting them, could at first glance be considered an independent decision. This is what certain microeconomic analyses using game theory claim (Maennig, 2002; Berensten, 2002). The work of the psychologist emphasizes the individual factors of vulnerability which predispose one to doping behavior (Laure, 2000). Without denying the interest of such approaches, we would like to look further at the actors and the methods of the professional cyclist system (PCS).

\footnotetext{
${ }^{18}$ El Pais, 15 January and 8 February 2009; La Libre Belgique, 17 January 2009.
} 
Several analyses corroborate this conception of doping as a systemic output (Louveau, Augustini, Duret, Irlinger \& Marcellini, 1995; Brewer, 2002; Stewart \& Smith, 2008). The relations of power and the dynamics of the political formations within the PCS have been extensively studied by Stokvis (2003), whereas Waser (1998) and Salle, Lestrelin \& Basson (2006) emphasize the study of environmental fluctuations affecting the regulation of doping. All these writings are coherent with our position which implies a focus on the network of people taking part in the development, the identification, the prevention and/or the repression of the doping methods brought to light by the Puerto operation.

\section{Insert here diagram 1}

In order to acutely comprehend the structure of a critical situation one has to not only list the protagonists (see diagram1) but also study the factors of vulnerability, their relations to each other, and the interdependent ties which contributed, in the Puerto affair, to the relative status quo mentioned above. Like any complex system, the PCS is source of unknowns and unpredictability as it can, through actions or decisions of its members, innovate and organize itself in order to adapt to its own changes or to the changes in its environment. The feedback loops and circular causality characteristic of the systemic approach make it possible to comprehend particularly complex and sometimes counter-intuitive phenomena. For instance, when certain decisions have contradictory effects, one can talk of ago-antagonism (Kervern, 1995): Kayser, Mauron and Miah (2005) claim, for example, that the current way of fighting against doping creates as many if not more problems than it prevents. Doping prohibition is described as not very efficient, as it possibly encourages the production and use of little known drugs which are thus not yet detectable (Caulkins \& Reuter, 2005) or even the use of masking substances which may be dangerous (Bird \& Wagner, 1997; Voy, 1991). A 
pernicious effect is then generated through the increase of the use of particularly harmful products (Stewart \& Smith, 2008). Another pernicious effect is found in the fact that cyclists resort to self-medication for fear of soliciting medical advice, sometimes using incorrect doses (Waddington, 2001).

Considering all this, the use of the Kervern model (1995) seems heuristically promising. It emphasizes the ambiguous effects of the actions and the decisions taken within a high-risk system; besides the ago-antagonism mentioned above, it points to the duplicity of some $\operatorname{actors}^{19}$. Not exclusively producing disorder or stability, these various elements can contribute to both, at the end of a complex causal process. This premise requires the reconstruction of the "social map" of the actors who influence the vulnerability of a system and/or the prevention of the risks that it carries. Once the network has been identified, Kervern suggests focusing on five dimensions which structure the functioning of such systems in order to facilitate the listing of biases which generate risks and/or crises.

\section{Insert here table 1}

Each of these fields supports the actions and decisions within a system. Loopholes can be found, due, for example, to a regulation which is inappropriate or badly implemented, or to insufficient scientific knowledge. A more thorough study exposes discordance between the dimensions or discrepancies between the actors (concerning their objectives, their value systems, etc.). All the ambiguities can contribute to the system's vulnerability, to its preventative efficiency as well as to counter-productive effects. The recent use of this model

\footnotetext{
${ }^{19}$ For example one can think of the doctor, who is a central figure in the history of doping. Let's not forget the basic ambiguity of sport medicine which aims both at protecting the health of the athletes and at optimizing their performance. Concerning the doctors, their many varied positions on doping, and their role in placing sanitary and medical perception at the center of regulation, see Salle (2004) and Salle and al. (2006).
} 
to study the generalization of doping among professional cyclists (Soule \& Bouhaoula, 2008) has led to interesting results. First, plural risk factors have been identified by analyzing the confrontations between actors within each dimension: heterogeneous levels of knowledge, contradictory values, rules established more or less clearly and more or less respected, etc. Furthermore, some emerging properties conducive to doping are found at the intersection of the dimensions. For example, establishing an official list of prohibited products (rule dimension) stimulates the search for alternative methods (knowledge dimension); the illicit nature of doping (rule dimension) associated with the cyclist subculture's code of silence (value dimension) leads to underestimating the scope of the problem (fact dimension); this affects the epidemiological knowledge of the effects of the products, which remains partial (knowledge dimension); finally the concern of preserving the image of cycling competition (goal dimension) drives some sports institutions to cover up ascertained doping. Furthermore, frequent procedural irregularities and long judicial delays, resulting in rare sanctions, diminish the credibility of available deterrents (rule dimension). This type of analysis leads to the conclusion that an understanding of the doping system requires the identification of complex interactions between factors which are not connected a priori. Our hypothesis is that it is valid to use a similar approach, based not only on the vulnerability of the PCS concerning doping, but more widely on the problematic nature of its prevention and regulation, demonstrated since operation Puerto.

\section{Method}

Like other deviant and/or illicit practices, doping evades factual analysis. Hence the limited production of data renders necessary a secondary exploitation of media and legal sources. Thus, we proceeded to analyze systematically articles published by the international press on 
the subject of the Puerto affair ${ }^{20}$, during a time period starting with the original revelations of Manzano (April 2004) and ending with the second re-opening of the case by the Spanish justice system (early summer 2009). Using this moment as the end of the period covered allows us not to chase after new media developments, which would be incompatible with the rhythm of research (Marchetti, 2002). Thus, it is clear that this article does not account for the entirety of this affair which is characterized by its many ramifications, several reversals of situation and the persistence of shady areas. An exhaustive description is hardly compatible with the format of a research paper. More circumscribed, our objective required the selection and interpretation, within the constituted corpus, of factual elements revealing the erratic character of the international governance of doping.

Among the material collected during this five-year analysis of the press, 60 articles taken from 18 European newspapers are used directly. L'Equipe, Le Monde, As, El Pais, Le Nouvel Observateur and Libération have been the most sollicited. Le Figaro has been used occasionally as well as Le Parisien, La Gazzetta dello Sport, L'Humanité, Marca, La Tribune, Le Temps, Le Soir, El Mundo, Le Journal Du Dimanche, La Libre Belgique and Der Spiegel. Finally, four press agency dispatches and one internet source were used.

The qualitative data collected (judicial rulings, commentaries of judicial reports, journalistic analyses, interviews and opinions of the protagonists) have been exploited using the Kervern model. It is worth noting that, contrary to Delmas and Fleuriel's observations (2002) concerning the way the media covers doping affairs, the articles published by the press show a

\footnotetext{
${ }^{20}$ Three databases were exploited: the daily press review of the Mission Interministérielle de Lutte contre les Drogues et la Toxicomanie; the thematic files constituted and published on line on two very well-documented sites (www.cyclisme.dopage.com and www.cyclingnews.com). The collection of data was completed by the documentary analysis made by M. Laville in his Masters Degree thesis (University of Caen-Normandy, 2008).
} 
certain critical distancing relative to the official sources and the institutional handling of this affair. Some journalists, anxious to counter these interpretations, clearly blamed the actions of the institutions through thorough investigations which facilitated our own approach to the facts and decisions.

\section{Results}

The difficulties of the fight against doping revealed by the Puerto affair are presented below in reference to each of the five dimensions of the Kervern model (1995). This is followed by a synthesis presented in the form of a diagram showing the relations between the identified factors of vulnerability and crisis.

\subsection{The fact dimension}

Two aspects will be treated in the first part of the results: first, a group of facts, all dated prior to 2006, which shows the spread and even a tacit tolerance for doping among professionals, particularly doping through autotransfusion; secondly, elements helping to conceal the disclosed practices and/or to minimize the scope of the network exposed by the raid of the Spanish Guardia Civil, such as hindering the production of or retaining judicial information, selectively revealing the identities of the athletes implicated in the affair, etc.

Perfected in the 1970s, doping through transfusion was more or less abandoned at the beginning of the 1990s in favor of EPO which has similar effects but requires less elaborate medical logistics. Since 2000, this ergogenic process has made a comeback, which can be explained by progress made in the detection of EPO (see below, the knowledge dimension). 
The extent of the problem is such that several doping specialists have expressed their concern: D'Ottavio, a member of the antidoping commission of the Italian Health Ministry, declared as early as 2003 that transfusion was one of the methods most used by cyclists ${ }^{21}$. Two days after the operation, the UCI stated that it had on several occasions informed the Spanish government and the WADA of its suspicions concerning the use of blood doping in Spain, thus requesting support in the investigations. Therefore, the type of doping "exposed" by the Puerto operation had already been used for a long time within the PCS. Furthermore, the actors involved had long been under suspicion. For example, the president of the RFEC declared on 28 June 2006 that he had always had doubts concerning Saiz and Fuentes ${ }^{22}$. More generally, it was the alarming spread of doping in Spain, due to a lax response officially recognized by the Zapatero government, which led to the implementation of a "zero tolerance" policy ${ }^{23}$ at the beginning of 2005 , resulting in the 2006 law which severely punishes these practices. From this angle, the Puerto affair is the result of a tacit tolerance for doping in Spain. Indeed doping, including transfusion doping, had long been performed by professional cyclists with the knowledge of several institutional actors which were supposed to prevent and punish such practices.

Another essential aspect emerges from operation Puerto: the difficulties and reticence encountered when gathering and producing information pertaining to the affair, as well as partial, selective and slow communication of the tangible elements contained in the files. As a consequence, evidence became scarce, rendering punishment difficult (see below, the rule

\footnotetext{
${ }^{21}$ Le Monde, 24 July 2003. In September 2004, the American rider Hamilton was suspended for two years for transfusion doping. He was already a "patient" of Dr Fuentes.

22 “We heard rumors [...] The police operation was necessary. We made mistakes in our fight against doping in Spain. Our duty was to investigate these frauds" (Associated Press dispatch of 28 June 2008).

${ }^{23}$ Libération, 17 February 2005.
} 
dimension). This is all the more surprising considering how substantial the seizures made by the Guardia Civil were, as was the gathering of phone conversations, photographs and video recordings by the investigators. Several signs point to hindrances situated at the intersections of judicial constraints and diverse strategies (see below, the objective dimension).

The State prosecutor deplored, for example, the fact that Judge Serrano had not made use of the data available on the computers seized by the Guardia Civil. We also know from a journalistic ${ }^{24}$ source that Dr Fuentes kept information concerning his "patients" in files in his Canary island residence. This residence was not searched, even though the judicial authorities could have easily done so. Consequently, the arrest of Dr Fuentes led to the identification of only a part of his "client records" 25 .

Moreover the hundred bags of blood were not all analyzed. Only eight bags were tested for EPO, all of which tested positive. None of the others were tested: the Barcelona antidoping laboratory in charge of the testing actually suspended its work because it had not been paid for the tests it had already done ${ }^{26}$. Lastly, the judge interviewed only 12 of the 58 first "Puertists", arguing that none of them had complained about health problems.

\footnotetext{
${ }^{24}$ Le Monde, 24 March 2007.

${ }^{25}$ These decisions were interpreted as a sorting of information with the goal of not publicizing the implication of other athletes (Le Monde, 7 December 2006). This article says that several Spanish football teams (including Real Madrid and FC Barcelona) were linked to Dr Fuentes. This claim caused the newspaper to be fined 300,000 euros following a complaint filed by Real Madrid. Le Journal du Dimanche of 2 February 2006 implicates tennis player Rafael Nadal as well as football payers.

${ }^{26}$ Le Monde, 7 December 2006. Continuing the testing ordered by the judge to identify the origin of the blood and detect traces of products is costly. The laboratory in charge of the testing stated that it would resume working only if it was paid the 25,000 dollars it was owed (El Pais, 16 January 2007).
} 
Besides this minimal production of information concerning the affair and its protagonists, the transmission of elements of the case to the varied sport authorities susceptible to issue sanctions was also problematic. A month after the operation, at an antidoping convention taking place in Paris, the President of the UCI expressed his doubts about the willingness of the Spanish authorities to cooperate. At the end of 2006 he officially deplored the lack of cooperation of the Spanish justice system ${ }^{27}$ which had refused to send him the information contained in the files. Judge Serrano had then argued that it was not possible to authorize the use of these documents as a basis for sport sanctions. On 23 April 2007, the UCI - through its president - the WADA and the International Olympic Committee (IOC) reacted by urgently appealing to the Spanish Minister of Sport and asking that the Puerto affair be thoroughly investigated $^{28}$. The request remained unheard. Almost three years after the beginning of the operation, the WADA president tried again to pressure the Madrid court into handing over the evidence collected during the investigation ${ }^{29}$. At the same time, in May 2009, the RFEC, prompted into action by the $\mathrm{CSD}^{30}$, tried to get access to the records. The request was denied by the judge who argued that there was no element indicating a public health violation.

These very timid attempts at gathering information, combined with the fact that the institutions in charge did not share data, prevent a full exposure of the affair or the punishment of its actors. As a result, the scope of the network is minimized and its structure remains unclear. The new antidoping legal framework introduced in Spain at the end of 2006 should permit a better understanding and clarification of the facts. It is a sign of recent

\footnotetext{
${ }^{27}$ In a letter addressed to the Spanish Ministry of Sport (Eurosport, 26 June 2007).

${ }^{28}$ Le Parisien, 24 April 2007.

${ }^{29}$ Le Nouvel Observateur, 28 February 2009.

${ }^{30}$ L'Equipe, 24 February 2009.
} 
eagerness on the part of the Spanish authorities, which is also apparent in the actions taken to identify and punish fans who cause trouble during sporting events ${ }^{31}$.

\subsection{The knowledge dimension}

The progress in scientific knowledge and the fine-tuning of antidoping tests produce a mix of opportunities and constraints for the PCS. Since 2000, progress in testing has rendered EPO detectable, leading the athletes to turn to autotransfusion, an equally performance-enhancing method which is undetectable ${ }^{32}$ (de Mondenard, 2006). The fact that detection is so difficult is probably the reason why the network exposed by the Puerto operation became so vast. That the evidence was discovered by the police shows how impotent the antidoping institutions were.

Current scientific knowledge allows a comparison between the bags of blood seized by the Guardia Civil and the deoxyribinucleic acid (DNA) of the riders under suspicion. This would confirm their involvement or clear them with almost no risk of error. However only two such comparisons have been performed: one, requested by the German judicial authorities, led to the conviction of Ullrich (see below, the rule dimension); the other, performed by the INOC, shows that Valverde, who had ranked number one in the UCI Pro Tour in 2006 and 2008, had

\footnotetext{
${ }^{31}$ Concerning racism and violence during sporting events, all the convictions are now systematically recorded in a central file. This document is managed by the Interior Ministry. It also keeps record of all the incidents affecting sporting competitions (place, date, type of offence, name of club and/or individual, sanction) (Salle, 2008).

${ }^{32}$ Autotransfusion can be indirectly indicated by the number of red cells in the blood. However it is still impossible to know precisely the method used to cause such a high hematocrit level: EPO, long-term exposure at high altitude, hyperbaric chamber, blood transfusion, etc.
} 
used Dr Fuentes's services ${ }^{33}$. It is worth noting that all the "Puertists" who were asked to submit to similar comparisons to prove their innocence refused to do so, giving various reasons (see below, the rule dimension and the value dimension). It is only under coercion or during later antidoping tests, that their blood was taken and the DNA testing performed. However several factors, which will be analyzed later, prevent the use of scientific methods which would ascertain that the blood seized in Dr Fuentes's Madrid apartment belongs to the suspected cyclists.

\subsection{The objective dimension}

In this section we will address the teleological priorities of several of the protagonists, particularly insofar as these priorities generate strategies preventing the identification of the network of the athletes involved and/or the issuing of various sanctions.

Following the revelations of May 2006 several teams terminated their riders' contracts and expressed their condemnation of the more indulgent team managers. But others took advantage of the opportunity created by these dismissals to hire recently sacked "Puertists" at a lower cost. This situation, resulting from an intense competition between the professional teams, on both sport and economic levels, is one of the endogenous factors which made the PCS remain conducive to doping. Indeed, expelling riders is not a very efficient deterrent when their performance level makes them attractive to other less discriminating teams. Moreover this opportunistic way of operating contributes to keeping the composition of the PCS unchanged, including the drug-using riders.

\footnotetext{
${ }^{33}$ Le Nouvel Observateur, 1 April 2009 ; L'Equipe, 24 February 2009.
} 
Another reason why this affair is important is that it involves a large number of cyclists.

Paradoxically, this may explain why the sanctions were so light: greater severity would have led to the exclusion of a large number of riders, including many Spanish star riders. Beyond that, a change of perspective is necessary to understand the stakes outside of the PCS. The list of the tennis players and professional football players who used the services of Dr Fuentes was never released (see above, the fact dimension). The cyclists were the only "Puertists" whose identities were exposed by the press and the only ones - some of them - who faced prosecution and/or sanctions.

The lack of cooperation of the Spanish judicial system, despite multiple and repeated requests, puts into question its willingness to facilitate the gathering of evidence and the investigation of the case (see below, the rule dimension). Pat McQuaid (president of the UCI) suggested on several occasions that the Spanish authorities were trying to hide something ${ }^{34}$. Besides, the petition for nullity filed by the State prosecutor on 22 March 2007 stipulates that the closing of the case was "precipitated and surprising" 35 . Is the goal to minimize the real scope of this embarrassing affair? Is it to protect Spanish top-level sport teams which are doing very well at the end of the 2000 's ${ }^{36}$ ? The emphatic though rather hasty assertions made by eminent

\footnotetext{
${ }^{34}$ Le Temps, 26 February 2008.

${ }^{35}$ Le Monde, 24 March 2007.

${ }^{36}$ Jaime Lissavetsky, Secretary of State and president of the CSD, called 2008 “ a magical year for Spanish sport": international titles were won in cycling (Tours of France, Italy and Spain, Olympic games), tennis (Davis Cup, Wimbledon and Olympic games) and football (European Championship). The head of the government, Jose Luis Zapatero said: "We are among the best countries in the world. Thanks to your success, it is easy to belong to the G8 of sport" (El Pais, 23 November 2008).
} 
representatives of the authorities, trying to minimize the scope of the network of athletes linked to Dr Fuentes ${ }^{37}$, reinforce the plausibility of this explanation.

A more direct antidoping expert explains that "when it comes to doping, Spain is the most problematic European country" ${ }^{38}$. According to the presidents of the UCI and the RFEC, "Spain is a doping paradise" $" 39$. This is confirmed by the doctor of a professional team who said: "it is generally admitted, except by the Spanish authorities, that Spain is the hub of European doping for every sport ${ }^{\prime 40}$. Even the Tour of Spain organizers stated that they were frustrated by the little progress made by the Spanish authorities in the Puerto affair, particularly when compared to the more radical actions taken against the "Puertists" in other countries $^{41}$. The director of this race emphasized that in Germany or in Italy the cyclists who were suspected of involvement were under a lot more pressure, whereas in Spain the presumption of innocence allowed the cyclists to enjoy relative clemency ${ }^{42}$. This situation is all the more surprising, as Spain is one of the European countries where the state plays a major role and the management of sport is centralized on the grounds that the promotion and development of sport are considered a public service (Miege, 2000) ${ }^{43}$.

\footnotetext{
${ }^{37}$ On 4 July 2006, Jaime Lissavetsky tried to be reassuring: "None of the football players or tennis players are involved" (Libération, 7 December 2006). Aimed at stopping claims that top-level Spanish football and tennis players were clients of Dr Fuentes, this denial was nevertheless contested by Dr Fuentes the next day.

${ }^{38}$ Le Temps, 26 February 2008 (the informant wanted to remain anonymous).

${ }^{39}$ Libération, 16 February 2008. The day after the Puerto operation the president of the RFEC declared that the antidoping bill would lead to the disappearance of the Spanish "doping paradise".

${ }^{40}$ Gerard Guillaume, doctor of the French team La Française des Jeux (L'Humanité, 19 July 2008).

${ }^{41}$ Reuters dispatch, 10 May 2007.

${ }^{42}$ As, 10 May 2007.

${ }^{43}$ Title 8 of the law of 15 October 1990 stipulates that "the CSD is in charge of implementing all the measures concerning the prevention, control and repression of doping” (Miege, 2000, p. 71). An ordinance from 1996
} 


\subsection{The rule dimension}

The Puerto affair, like the Festina affair eight years earlier, did not start with a positive antidoping test. The government took charge, using police enforcement and the law, thus replacing the sport authorities with common justice (Basson, 2001). However, more than three years after the seizures of the Puerto operation, it is obvious that using the judicial system only had a moderate impact.

To this day the Spanish justice system has not allowed any sport organization to use elements contained in the files as a basis for sport sanctions, thus rendering the suspected riders and managers almost untouchable ${ }^{44}$. Only four riders were suspended by the Italian Cycling Federation (ICF), after admitting their guilt to the $\mathrm{INOC}^{45}$ : Basso (for 2 years) and Scarponi (for 18 months); Valverde, banned from racing in Italy for two years ${ }^{46}$; Jaschke, suspended for a year by the Austrian Cycling Federation, also after admitting guilt ${ }^{47}$.

states the procedures through which the laboratories are approved and controlled; a decree of the same year establishes sanctions; and a resolution of the CSD dated 11 February 1997 lists the methods and products which are prohibited. Contrary to the law voted in November 2006, this law did not make provisions for legal sanctions and did not address the case of the dealers.

${ }^{44}$ Thus "cleared", the "Puertists" were able to get another license and, for some, to find another team. However the UCI expressed its discontent over having to give his Pro Tour license back to Manolo Saiz.

${ }^{45}$ Concerning Basso, the INOC threatened him with DNA testing which was possible after 1) it had obtained blood samples from a Barcelona laboratory in charge of testing; 2) it had taken a blood sample from Basso during a antidoping spot-check. The winner of the 2006 Tour of Italy and 2005 Tour de France challenger of Armstrong then admitted his guilt. Scarponi did the same shortly after.

${ }^{46}$ L'Equipe, 14 May 2009. Heavy with consequence, this ban kept Valverde from participating in the 2009 Tour de France, the $16^{\text {th }}$ leg of which taking place in the Aosta Valley in Italy (Le Figaro, 18 May 2009; Le Monde, 15 
Spanish law is not very suitable for sanctions taken by the justice system either; indeed one of the obstacles in the identification of the "cheaters" is the necessity to find a criminal context in which to organize the search for evidence. If it is exaggerated to claim that this context did not exist in Spain at the time of the affair (see above), the production, use and distribution of doping products only became punishable by law (with sentences as high as 2 years in prison) after the fact, in November 2006. Because the laws are not retroactive, the facts and practices recorded by the Guardia Civil cannot be punished under this new law. Consequently it is legally impossible to initiate a procedure of identification of the blood bags through DNA analysis with the aim of legal sanctions.

A digression is necessary to explain the specific procedure which allowed the exposure of Ullrich after a DNA test. Because at the time there was no antidoping law in Germany, the German justice system used an alternative approach to demonstrate that Ullrich was guilty, charging him with fraud and cheating the public, the sponsors and his teammates. The rider had actually used doping methods although he had signed, with his team T-Mobile, a document stating that he would not use prohibited products. Thus he had received salaries which would not have been paid had his employer known about his doping. This legal concept had never yet been applied in a case of suspected doping ${ }^{48}$. Following the DNA test which proved the German rider's guilt (his blood was found in nine of the bags seized in Dr Fuentes's laboratory) the Bonn prosecutor's office offered him a deal: he would admit his guilt and pay 250,000 euros to various charities and to the public treasury, and in exchange June 2009). The Spanish cyclist appealed this sanction to the CAS, but the decision was not handed before the beginning of the Tour de France (Le Monde, 23 June 2009).

${ }^{47}$ La Tribune, 19 September 2007; Le Monde, 28 July 2007; Der Spiegel, 30 June 2007.

${ }^{48}$ Le Nouvel Observateur, 10 March 2008. 
the investigation would be terminated and the case closed. The cyclist paid, the procedure was dropped and, because of this agreement, Ullrich is no longer considered guilty of a felony.

Other procedural possibilities were explored: in Spain, public endangerment and public health violations were successively invoked as a basis for prosecution but could not lead to the designation of culprits because evidence of harmful effects on the health of the cyclists has not been demonstrated. Even though blood transfusions are recognized as dangerous and it has been proven that several cyclists have used this doping method ${ }^{49}$, it is difficult to show that a person has been exposed to a risk as long as this person is healthy, as is the case for the "Puertists". More than three years after the operation, the judicial soap opera is still running. The second reopening of the case mentioned at the beginning of the article is motivated by two presumptions of penal code violations ${ }^{50}$ : did Dr Fuentes and his network respect the legal rules concerning the conditioning of medication (uninterrupted cold chain for the blood bags; conditions of preservation of products like EPO)? Were the medical procedures (taking and/or injecting blood) performed by licensed practitioners? Doping is no longer at the center of the legal battle. The consequence of the fact that alternative approaches are being used is that only doctors are now under investigation, the riders and sport managers being called as simple witnesses if necessary.

One last aspect concerning the rule dimension has to be mentioned. Many organizations could a priori control violations, issue sanctions, and/or pronounce arbitration: the UCI, national federations, the WADA, the CAS (Court of arbitration for Sport), judicial institutions of every

\footnotetext{
${ }^{49}$ Several newspapers published excerpts from the report by Judge Serrano stating on 12 March 2007 that although he was convinced that the cyclists had used autotransfusion for doping purposes, the evidence was not sufficient to constitute a public health violation.

${ }^{50}$ Libération, 16 February 2008.
} 
country, Ministries or State Secretaries of sport, national Olympic Committees, the IOC, etc. ${ }^{51}$ This situation has several consequences: the variety of goals and the diverging priorities but also the contradictions, and even judicial incompatibilities, which can lead to the dilution of responsibilities, to the blocking of situations and, incidentally, to long delays between respective procedures ${ }^{52}$. For example, the UCI, swift in its denunciation of the lack of cooperation of the Spanish justice system and authorities, claimed that it was impossible to hand in the blood samples it possessed for the purpose of DNA analysis. The samples are scientifically tested and the UCI rules forbid their transmission for other use $\mathrm{e}^{53}$.

The competition between these various legal frameworks allows protagonists to play with the rules in a way that is revealing of their strategies. The hesitations surrounding the case of Valverde, a Spanish cyclist, are very telling. On 29 August 2007, based on the information exposed in the second Puerto file, the UCI barred him from participating in the World Championship. On 7 September, the RFEC refused to take any disciplinary measure against Valverde, announcing its intention to select him. The Spanish Secretary of Sport expressed support for the rider, emphasizing the lack of new elements proving his involvement in Dr Fuentes's network. This stand taken by the Spanish government led to a letter from the president of the UCI to the Secretary of Sport, pointing to damning evidence of Valverde's guilt and deploring the lack of transparency shown by the Spanish government.

\footnotetext{
${ }^{51}$ Moreover 12 of the 17 autonomous Spanish communities have jurisdiction and their own laws governing sport. The CSD is supposed to coordinate their action, particularly concerning top-level sport, the fight against doping or violence (Miege, 2000).

${ }^{52}$ For example, the RFEC waited for official notification of the case being closed before it reacted: " when we get it, we will make a decision. It will depend on what has been decided by the prosecution which can appeal the decision of the judge" (Libération, 13 March 2007).

${ }^{53}$ Associated Press dispatch, 10 August 2006
} 
The CAS, arguing that it did not have sufficient elements to bar Valverde from racing, allowed him to participate in the World Championship ${ }^{54}$. The WADA and the UCI unsuccessfully requested from the Spanish judge access to a blood bag labeled with a code supposedly designating Valverde in order to perform a DNA test. The pouch was then requested by the CAS but the request was denied by Judge Serrano, arguing that the "private organization" status of the CAS rendered impossible the transmission of evidence. This denial led, on 11 July 2008, to the UCI and the WADA jointly filing an appeal to implement the decision of the CAS. In July 2008, the CAS gave the Spanish justice system six months to hand over the blood bag ${ }^{55}$.

Valverde is also at the center of another imbroglio. Taking advantage of a brief moment when the 2008 Tour de France was going through Italy, the INOC gave Valverde a blood test. A DNA comparison of that blood with a blood sample seized during the Puerto operation allowed the INOC to confirm that the latter belonged to Valverde. Supported by the UCI, the antidoping court of the INOC then pronounced the sanction mentioned above for the violation of the WADA code.

The Spanish cyclist filed a complaint, arguing that the INOC had not respected the prohibition from using elements of the Puerto files that had been issued by the Spanish justice system ${ }^{56}$. His team (Caisse d'Epargne) accused the INOC of being incompetent and characterized the procedure as irregular. The Madrid Superior Court declared invalid the procedure used by the

\footnotetext{
${ }^{54}$ The decision of the CAS (2007/O/1381 RFEC \& Valverde $\left.\mathrm{c} / \mathrm{UCI}\right)$ can be consulted on its website.

${ }^{55}$ Marca, 14 April 2008; L’Equipe, 11 July 2008.

${ }^{56}$ Le Nouvel Observateur, 6 May 2009.
} 
INOC for gathering evidence, arguing 1) that because it was not a representative of the Italian justice system, the INOC did not have the right to request from Spain blood samples susceptible to establish Valverde's guilt ${ }^{57}$; and 2) that the evidence gathered during the Spanish investigation could not be used in another affair ${ }^{58}$. The president of the Spanish Olympic Committee also asserted the innocence of Valverde. The RFEC completed this front of support for Valverde, arguing that it is "the only organization allowed to impose disciplinary sanctions in doping cases" $"$. Finally there was nearly a diplomatic incident when the Spanish Secretary of Sport declared that it was the responsibility of the Spanish Justice system to judge this Spanish citizen.

According to the INOC antidoping prosecutor, Valverde's lawyers present at his hearing did not respond to the accusations, claiming only that the Italian authorities did not have the legitimacy to act in this affair. This is not "playing by the rules" based on the existence, absence, and/or pertinence of factual evidence, but rather "playing with the rules" (Boudon \& Bourricaud, 1982), with a focus on the legitimacy of the actors, the legal framework and the procedures, aimed in fine at reducing - or even at preventing - the judicial and/or disciplinary sanctions against this rider.

It is easy to perceive the limits of a regulating system confronted with difficulties in characterizing the behaviors it is supposed to punish, with diverse legal and regulatory frameworks, and which, on top of everything, is subject to an unwilling judicial authority.

\footnotetext{
${ }^{57}$ L'Equipe, 18 February 2009.

${ }^{58}$ Le Nouvel Observateur, 1 April 2009.

${ }^{59}$ Le Figaro, 18 May 2009.
} 


\subsection{The value dimension}

Some solemn agreements foreboding self-regulating capacities in the PCS had no effect. For example, the ethical code proposed by the UCI and signed by all the Pro Tour teams in the immediate aftermath of the first revelations of May 2006 consisted of a moral commitment to fire anybody convicted of doping, to temporarily bar from competition all the riders under investigation and not to hire any rider before a ruling had been issued by a judge ${ }^{60}$. Faced with hiring opportunities, several teams paid no heed to this agreement, as attested by the contracts signed by many "Puertists" between 2006 and 2008 (see above, the objective dimension) ${ }^{61}$. The dissonance between the axiomatic dimension and the teleological one is striking.

Moreover, the other athletes a priori involved in the Puerto affair are not negligible: football players from FC Barcelona, Real Madrid and FC Valencia, top tennis players, etc. These athletes were revered as long as they made Spain a leading nation in sport in the 2000's: "The problem is that in Spain gods are untouchable! [...] In Italy they do the right thing [...] if they have to accuse Basso, they do it. Here, if a champion is implicated, we cover up for him $" 62$.

Finally, beyond the commitments which were not honored and the special status attributed to some athletes, hiding behind grand principles permits a justification - sincere or cynical - of certain actions or attitudes. For example, one can, like Dr Fuentes, invoke medical ethics to

\footnotetext{
${ }^{60}$ This last point was approved by the members of the AIGCP (Association Internationale des Groupes Cyclistes Professionnels), through a verbal commitment, in October 2006.

${ }^{61}$ The opportunities were all the more attractive because this hiring took place in an imbalanced context, the teams offering most of the "Puertists" salaries lower than what their sport ranking allowed them to aspire to.

${ }^{62}$ Comments made by former rider Manzano (Le Monde, 11 December 2006).
} 
justify doping in athletes who were in the past allegedly endangered not by ergogenic

practices but by the inhuman sport challenges that are imposed on them ${ }^{63}$. More frequently, some principles are used to hinder a thorough control of the professional activities of the athletes: presumption of innocence, protection of privacy, mention of their status as ordinary citizens and religious considerations are, for example, used to justify their refusal to submit to blood testing. Thus Ullrich justified his refusal to submit to a DNA test declaring that he is " $a$ professional cyclist and not a murderer or a criminal". Massimo Martelli, Basso's attorney, declared on 5 September 2006, following an appeal by McQuaid for the "Puertists" to provide a blood sample for DNA testing purposes, that his client would never submit to a DNA test which would constitute an unnecessary and inappropriate intrusion into his private life.

\section{Synthesis and discussion}

The structure of this article may lead to the idea that the model chosen was essentially used to characterize the various elements preventing an efficient regulation of doping. However the model's contribution is not limited to this purpose. We first tried to reveal the blockages stemming from confrontations within each dimension. Diagram 2 illustrates and synthesizes this approach, focusing on the factors of the increase of doping through autotransfusion in professional cycling.

\section{Insert here diagram 2}

\footnotetext{
63 "Whether the drug used to protect them is listed as a doping product is of secondary importance" (Le Monde, 2 September 2006).
} 
Moreover, emerging properties (linked to mutual reinforcement between factors, cause and effect relations, etc.) adverse to the fight against blood doping appear at the intersection of the dimensions. The diagram below (diagram 3) presents a simplified version of some of these interactions, focusing this time on the difficulties encountered after operation Puerto. The effects are in bold.

\section{Insert here diagram 3}

Without overestimating its interest, it is worth noting that the Kervern model, as it is used here, allows us to connect more easily the available information relating to the Puerto affair while contributing to the partial disclosure of the way the PCS handles doping ${ }^{64}$. In this sense, it is systemic: the analysis, by making possible the identification of elaborate causal links, leads to the emergence of new properties within the system. Indeed, understanding the doping mechanism requires a comprehension of the interactions existing between factors which are $a$ priori insignificant and unconnected and of the decisions made at different times and involving actors belonging to various organizations. The exposed contradictions, characteristic of a complex social system, result in slow procedures, giving a reprieve to the actors involved, a majority of whom are still active within the PCS. The judicial and sport authorities do not work within the same timeframe.

It would be tempting to suggest an international breakdown of the governance of doping in relation to Puerto affair. In fact this affair reveals failures in the way problems inherent to

\footnotetext{
${ }^{64}$ Each modelization is a specific look at reality; it is not aimed at being exhaustive - which would be illusory but it must account for the properties and relations considered essential and pertinent. Thus a compromise has to be found between a reductive simplification and an exhaustive perfectionism: regardless of the efforts, "the real mistake would be to think that everything is understood" (Le Moigne, 1990).
} 
sport are managed, and it illustrates the necessity of outside regulatory intervention. Hence governance is taken in its systemic acceptation, its purpose being to account for the interdependence and the necessary inter-organization regulations in a complex situation: doubts concerning the environment, multiple actors serving diverging interests (public, associative, commercial) and multiple levels of coordination (Bayle \& Chantelat, 2007). The Puerto affair shows that it is necessary to switch from a vertical and centralized regulation to a horizontal coordination, favoring the notions of network, compromise and shared power (Bayle \& Chantelat, 2007). Governance then refers to the coordination problems stemming from the diversity of actors, scenes and forms of interaction (Lascoume \& Le Gales, 2007) which creates "disorder" (Gaudin, 2002).

Several elements also motivate the use of the term "crisis": the large and increasing number of protagonists; the existence of heated controversies exacerbated by conflicting interests; the spectacular coverage of the affair by the media; the weakening of the legitimacy of key actors of the PCS and of the fight against doping ${ }^{65}$. Moreover, the difficulty experienced when attempting to understand the affair in all its dimensions and the discordant cohabitation of the judiciary, government and sport actors also point to calling this affair a crisis. Finally, beyond the blurring of roles and the weakening of the organizational structure, which according to Weick (1993) characterize a crisis situation, the antidote constituted by the urgent organization of networks of actors (Kervern, 1995) was not very efficient, thus accentuating the impression that there was no governance.

\footnotetext{
${ }^{65}$ It is undeniable that the WADA did not play its role of coordination of the various legal and sport antidoping mechanisms.
} 
However, crisis contexts, by definition limited in time, generally come with attempts to restore the original order. Is this desirable, even though this case shows a lack of stability of the initial order, a limited resilience of the actors and even a certain degree of duplicity on the part of some protagonists? Rather than qualifying the present situation as a crisis of governance, an appealing but inappropriate expression, it is preferable to say that it is the gradual and belated establishment of a European - and maybe worldwide - governance of doping. While erratic and the object of numerous difficulties and oppositions, the governance of doping has been put on the political agenda, thus making it possible to envision the "crisis" as an opportune moment to hasten change, to clarify the responsibilities and rights of each protagonist and to reorganize the international regulation of doping.

\section{References}

Amalberti, R. (2002). Les effets pervers de l'ultra sécurité : application à la sécurité transfusionnelle. La gazette de la transfusion, 174, 5-7.

Berentsen, A. (2002). The Economics of Doping. European Journal of Political Economy, $18(1), 109-127$.

Bird, E.J., \& Wagner, G. (1997). Sport as a common property resource, Journal of Conflict Resolution, 41(6), 749-766.

Basson, J.C. (2001). Sport et ordre public. Paris: La documentation française - IHESI.

Bayle, E., \& Chantelat, P. (2007). Introduction. In E. Bayle \& P. Chantelat (Eds.) La gouvernance des organisations sportives (pp. 11-26). Paris: L'harmattan.

Boudon, R., \& Bourricaud, F. (1982). Dictionnaire critique de la sociologie. Paris: PUF. 
Brewer, B. (2002). Commercialization in Professional Cycling 1950-2001: Institutional Transformations and the Rationalization of "Doping". Sociology of Sport Journal, 19(3), 276301.

Caulkins, J.P., \& Reuter, P. (2005). Re-defining the goals of national drug policy: recommendation from a working group. American Journal of Public Health, 85(8), 10591063.

Chappelet, J.L. (2007). La gouvernance du Comité International Olympique. In E. Bayle \& P. Chantelat (Eds.) La gouvernance des organisations sportives (pp. 27-48). Paris: L'harmattan. De Mondenard, J.P. (2006). Dictionnaire du dopage. Substances, procédés, conduites. Paris: Masson.

De Leseleuc, E. \& Marcellini, A. (2005). Légitimité vs illégitimité du dopage chez les sportifs de haut niveau. Comment se définissent les limites du non acceptable ? Revue internationale des sciences du sport et de l'éducation physique, 70(4), 33-47.

Delmas, C., \& Fleuriel, S. (2002). Une vision enchantée de la vie professionnelle. L'éthique à l'épreuve des conditions de travail sportif et journalistique. Les Cahiers du Journalisme, 11, $34-47$.

Duret, P. \& Trabal, P. (2001). Le sport et ses affaires. Une sociologie de la justice de l'épreuve sportive. Paris: Métailié.

Gaudin, J.P. (2002). Pourquoi la gouvernance? Paris: Presses de Sciences Po.

Hoberman, J.M. (1992. Mortal engines: the science of performance and the deshumanization of sport. New York: The Free Press.

Kayser, B., Mauron, A., \& Miah, A. (2005). Legalisation of Performance-enhancing Drugs. The Lancet, 366, 21.

Kervern, G.Y. (1995). Eléments fondamentaux des cindyniques. Paris: Economica. Lascoume, P., \& Le Gales, P. (2007). Sociologie de l'action publique. Paris: Armand Colin. 
Laure, P. (2000). Dopage et société. Paris: Ellipses.

Louveau, C., Augustini, M., Duret, P., Irlinger, P., \& Marcellini, A. (1995). Dopage et performance sportive. Analyse d'une pratique prohibée. Paris: INSEP.

Maennig, W. (2002). On the Economics of Doping and Corruption in International Sports. Journal of Sports Economics, 3(1), 61-89.

Le Moigne, J.L. (1990). La modélisation des systèmes complexes. Paris: Dunod.

Marchetti, D. (2002). Sociologie de la production de l'information. Cahiers de la Recherche sur l'Education et les Savoirs, 1, 17-32.

Miege, C. (2000). Les organisations sportives et l'Europe. Paris: INSEP.

Rabenstein, R. (1997). Some facts about the history of doping in cycling competition. In N.

Oddy \& R. Van der Plas (Eds.), $8^{\text {th }}$ International Cycle History Conference (pp. 119-130). Glascow: Van der Plas Publications.

Salle, L. (2004). Le gouvernement du dopage en France. Entre pouvoirs publics, acteurs sportifs et médecins. La production de la loi de 1999 comme illustration. Thèse de doctorat, Université de Rouen.

Salle, L. (2008). Prévention et lutte contre les violences sportives : le cadre institutionnel espagnol. In A. Tsoukala, J.C. Basson, L. Lestrelin \& L. Salle (Eds.), Les enjeux des dispositifs actuels de lutte contre le hooliganisme en Europe (pp. 43-89). Paris: INHES.

Salle, L., Lestrelin, L., \& Basson, J.C. (2006). Le tour de France 1998 et la régulation du dopage sportif : reconfiguration des rapports de force. Revue internationale des sciences $d u$ sport et de l'éducation physique, 73(3), 9-23.

Soule, B., \& Bouhaouala, M. (2008). Analyse systémique et stratégique du dopage sportif : le cas du cyclisme professionnel. Revue Suisse de Sociologie, 34(3), 575-592.

Stewart, B., \& Smith, A. (2008). Drug Use in Sport. Implications for Public Policy. Journal of Sport \& Social Issues, 32(3), 278-298. 
Stokvis, R. (2003). Moral Entrepreneurship and Doping Cultures in Sport. ASSR Working Paper, Amsterdam School for Social Science Research.

Thoenig, J.C. (1994). La gestion systémique de la sécurité publique. Revue Française de Sociologie, 35(3), 357-392.

Voy, R. (1991). Drugs, sport and politics. Champaign: Leisure Press.

Waddington, I. (2001, April). Doping in sport: Some issues for medical practitioners. Paper presented at the Leiden International Medical Students Congress, University of Leiden Medical School, Leiden, the Netherlands.

Waser, A.M. (2000). De la règle du jeu au jeu avec la règle. In F. Siri (Ed.), La fièvre du dopage (pp. 187-198). Paris: Autrement.

Weick, K.E. (1993). The Collapse of Sensemaking in Organizations: the Mann Gulch Disaster. Administrative Science Quarterly, 38(4), 628-652. 


\section{Diagram 1: the main protagonists of the Puerto affair}

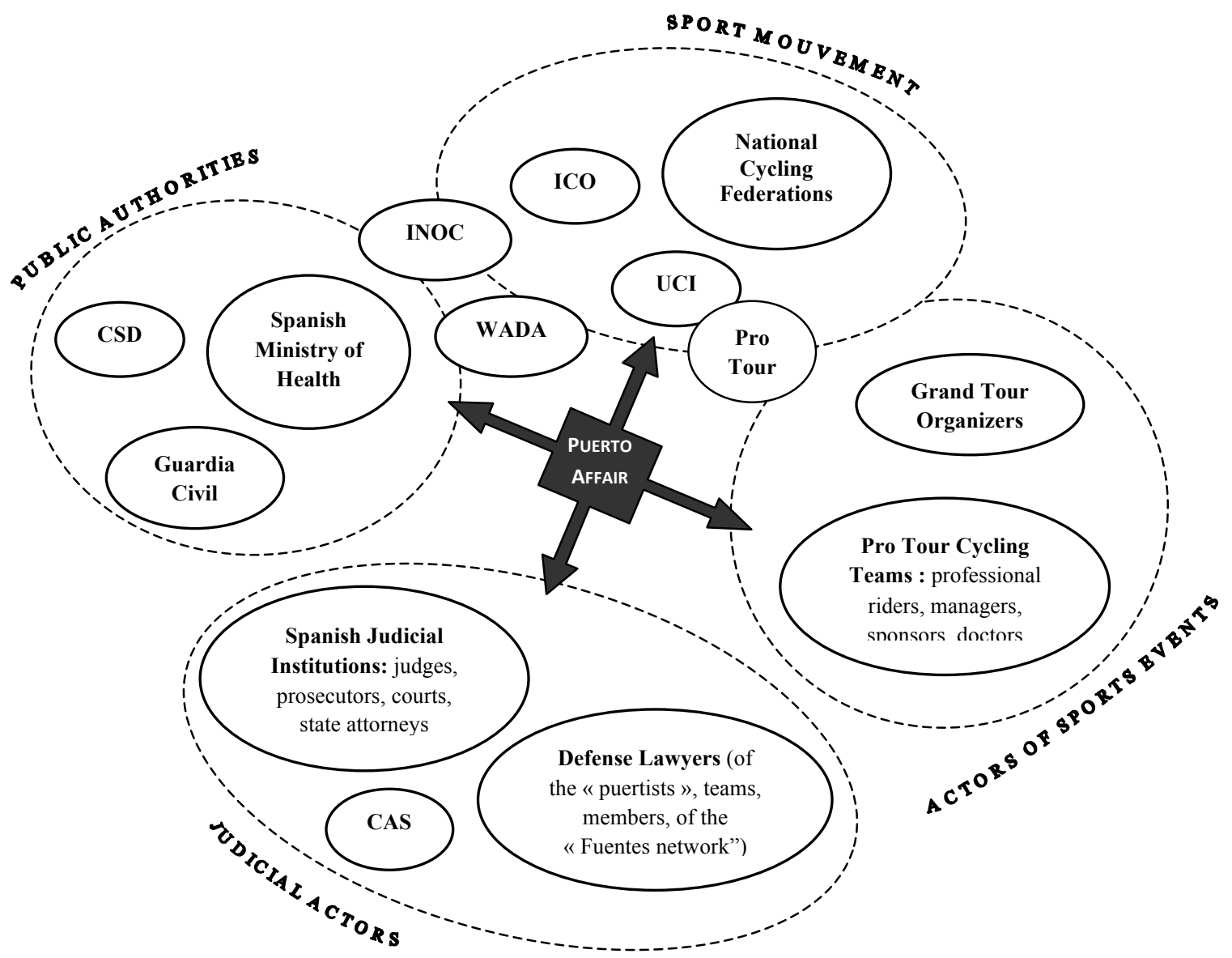


Table 1: the five dimensions of the Kervern model (1995)

\begin{tabular}{|c|c|c|}
\hline Dimensions & Description & Each actor of the PCS \\
\hline $\begin{array}{l}\text { 1. Teleological } \\
\text { (objectives, } \\
\text { interests) }\end{array}$ & $\begin{array}{l}\text { The goals of the actors, } \\
\text { inevitably contradictory, lead to } \\
\text { conflicts of interest }\end{array}$ & $\begin{array}{l}\text { - Pursues goals which can converge } \\
\text { or diverge from the strategies of } \\
\text { other actors }^{66}\end{array}$ \\
\hline $\begin{array}{l}\text { 2. Statistical } \\
\text { (facts, data) }\end{array}$ & $\begin{array}{l}\text { Conscience and memorization of } \\
\text { accidental facts and past } \\
\text { incidents }\end{array}$ & $\begin{array}{l}\text { - Knows more or less the data } \\
\text { concerning doping and current } \\
\text { practices } \\
\text { - Sometimes collects and stores } \\
\text { information }\end{array}$ \\
\hline $\begin{array}{l}\text { 3. Epistemic } \\
\text { (knowledge, }\end{array}$ & $\begin{array}{l}\text { Diverse forms of knowledge, } \\
\text { emanating from various sources, }\end{array}$ & $\begin{array}{l}\text { - Possesses and/or produces } \\
\text { empirical or scientific knowledge }\end{array}$ \\
\hline
\end{tabular}

${ }^{66}$ The organizations which manage the risks generally consider safety, a public issue, an absolute priority.

Beyond the discourse, safety goals are varied (Amalberti, 2002) and particular interests sometimes supersede the safety goals (Thoenig, 1994). 


\begin{tabular}{|c|c|c|}
\hline models) & $\begin{array}{l}\text { of the high-risk phenomenon } \\
\text { Allows a risk model. }\end{array}$ & $\begin{array}{l}\text { (physiological, chemical, etc.) on } \\
\text { doping, its effects, its detection, etc. }\end{array}$ \\
\hline $\begin{array}{l}\text { 4. Deontological } \\
\text { (rules, norms, laws) }\end{array}$ & $\begin{array}{l}\text { This dimension is "the rules of } \\
\text { the game" of the system }\end{array}$ & $\begin{array}{l}\text { - Designs, implements and/or } \\
\text { conforms (more or less drastically) } \\
\text { to diverse rules }\end{array}$ \\
\hline $\begin{array}{l}\text { 5. Axiological } \\
\text { (values) }\end{array}$ & $\begin{array}{l}\text { Value systems underlie human } \\
\text { action. They influence decisions } \\
\text { and reactions when facing risk }\end{array}$ & $\begin{array}{l}\text { - Is not insensitive to certain values } \\
\text { which one can respect or defend if } \\
\text { they are threatened }\end{array}$ \\
\hline
\end{tabular}

\section{Diagram 2: multidimensional synthesis of the process leading to the emergence of doping through autotransfusion}

KNOWLEDGE

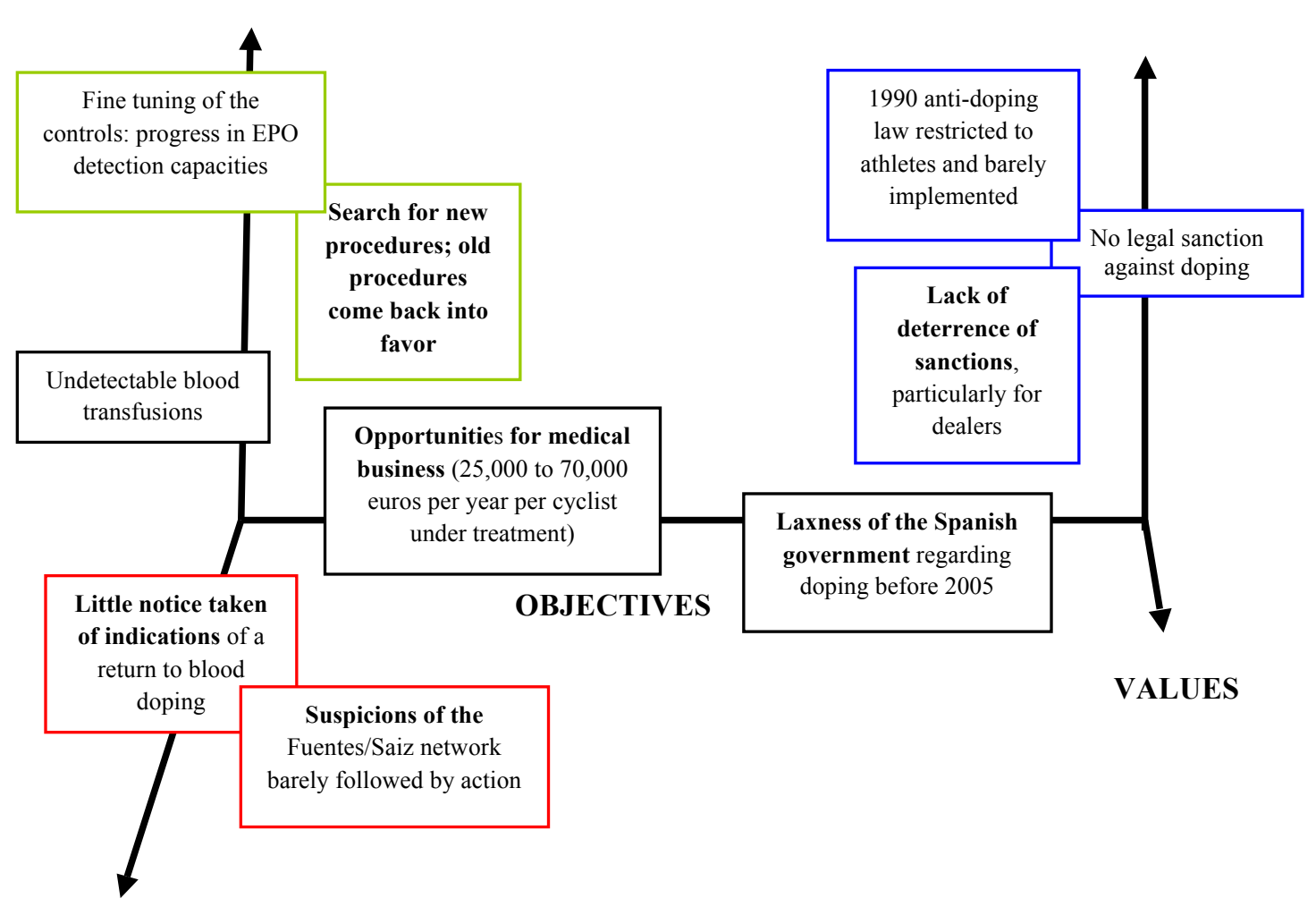

\section{FACTS}




\section{Diagram 3: multidimensional synthesis of the processes contributing to the regulatory}

\section{difficulties a posteriori}

RULES

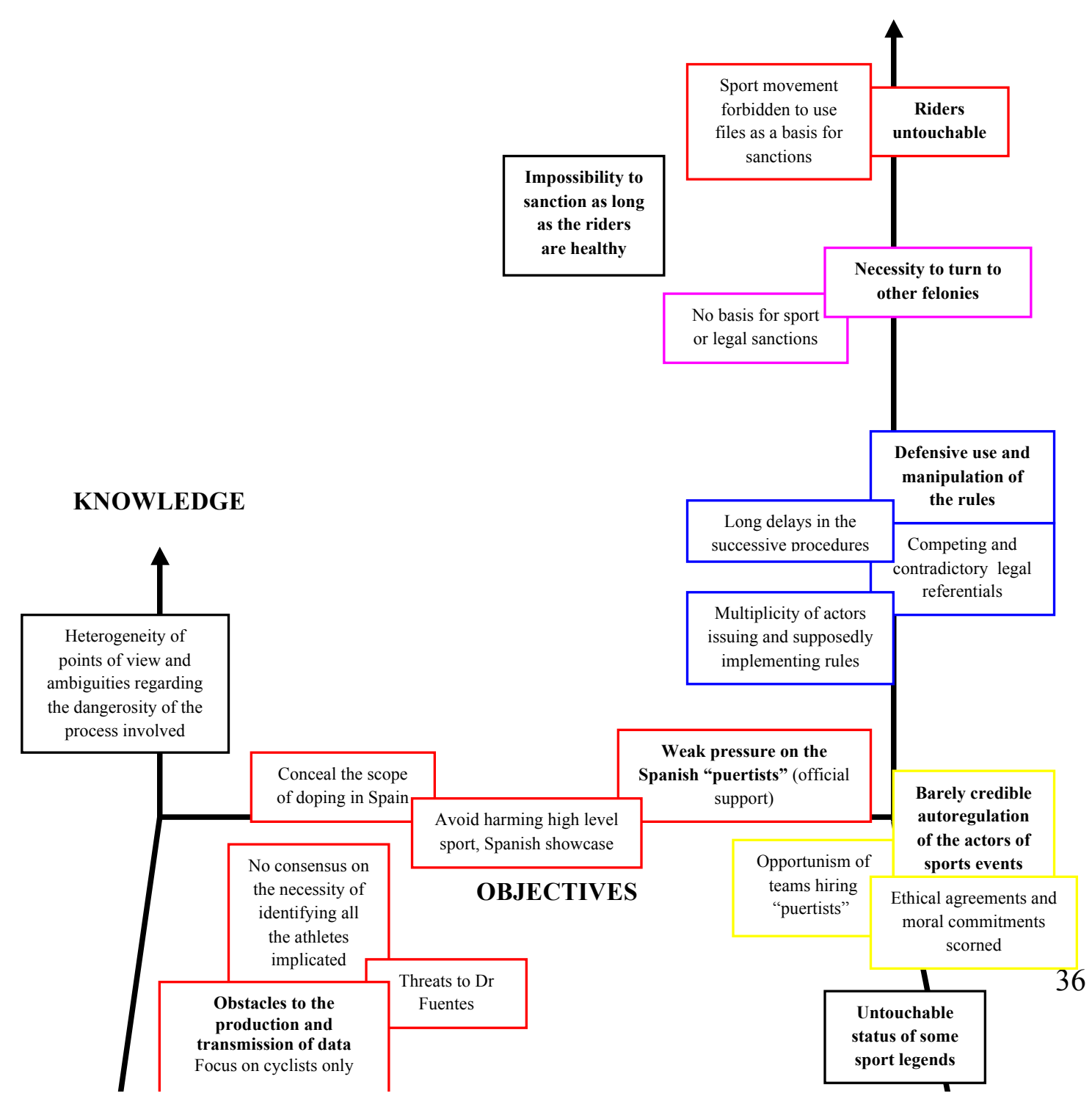


